Jurnal Agro 5(1), 2018

\title{
PERUBAHAN MORFOLOGIS DAN ANATOMIS KELAPA SAWIT PADA REZIM AIR DAN SALINITAS BERBEDA
}

\section{PALM OIL MORPHOLOGICAL AND ANATOMICAL CHANGES UNDER DIFFERENT WATER REGIME AND SALINITY LEVEL}

\author{
Erick Firmansyah \\ Fakultas Pertanian Institut Pertanian Stiper Yogyakarta \\ Korespondensi: erick@instiperjogja.ac.id \\ Diterima 15 Januari 2018 / Disetujui 21 Juni 2018
}

\begin{abstract}
ABSTRAK
Salinitas tinggi dan genangan dapat terjadi pada tempat dan waktu yang sama; meskipun demikian pemahaman terhadap pengaruh kedua kondisi tersebut terhadap pertumbuhan, respon morfologis, dan anatomis kelapa sawit masih sedikit. Telah dilakukan penelitian dengan mengkombinasikan 2 aras salinitas (non salin dan salin) dan tiga taraf genangan (tanpa genangan, interval genangan 2 minggu, dan interval genangan 4 minggu). Penelitian dilakukan dalam pot selama 4 bulan dengan bahan tanam kelapa sawit berumur 4 bulan. Parameter pertumbuhan dianalisis dengan analisis varian dan dilanjutkan dengan uji jarak berganda Duncan pada jenjang nyata $5 \%$. Pengamatan visual secara langsung dan pembuatan preparat melintang akar dilakukan untuk mengetahui perubahan morfologi dan anatomi tanaman. Hasil analisis menunjukkan salinitas tinggi dan genangan konsisten menurunkan parameter pertumbuhan kelapa sawit. Salinitas tinggi dan genangan tidak secara konsisten mengubah rasio luas masing-masing jaringan penyusun akar primer, sekunder, dan tersier. Kelapa sawit membentuk pneumatophore dan saluran aerenkima pada kondisi genangan, baik non salin maupun salin. Mekanisme adaptasi terhadap genangan tersebut dapat menurunkan pengaruh negatif cekaman salinitas tinggi.
\end{abstract}

Kata kunci: Abiotik, Cekaman, Genangan, Kelapa Sawit, Salin.

\begin{abstract}
High salinity and waterlogging can occur at the same place and time; however, the effects of these two conditions on growth, morphological, and anatomical responses of oil palm was not fully understood. A research had been done by combining two levels of salinity (non saline and saline) and three levels of waterlogging (without waterlogging, two-week waterlogging intervals, and four-week waterlogging intervals). The study was conducted in pots for 4 months used 4 months old oil palm planting material. The growth parameters were analyzed by analysis variance continued by Duncan multiple-range test at $5 \%$ level of convidence. The morphological and anatomical changes of plants were observed trought direct observation and root cross section. The results showed that high salinity and waterlogging consistently decreased the oil palm growth parameter. High salinity and waterlogging did not consistently
\end{abstract}

Cyte this as: Firmansyah, E. (2018). Perubahan morfologis dan anatomis kelapa sawit pada rezim air dan salinitas berbeda. Jurnal Agro, 5(1), 13-29 https://doi.org/10.15575/1963 
change the ratio of the area of each primary, secondary, and tertiary root tissue. Palm oil formed pneumatophores and aerenchyma under both non saline and saline waterlogging. Adaptation mechanisms to these waterlogging could reduce the negative effects of high salinity stress.

Key words : Abiotic, Oil Palm, Saline, Stress, Waterlogging.

\section{PENDAHULUAN}

Perubahan iklim, lingkungan budidaya yang tidak sesuai, dan praktek pertanian yang salah dapat menyebabkan kelapa sawit menghadapi berbagai macam kondisi lingkungan yang tidak ideal. Salinitas tinggi dan genangan merupakan dua dari sekian banyak kondisi lingkungan yang semakin sering dialami oleh kelapa sawit.

Genangan pada zona perakaran merupakan salah satu cekaman lingkungan utama yang dihadapi oleh kelapa sawit di lahan budidaya (Koon \& Kun, 2006). Air yang menggenangi perakaran memiliki salinitas beragam, bahkan pada beberapa kondisi memiliki salinitas tinggi, terutama lahan yang masih dipengaruhi pasang surut air laut melalui badan - badan air / sungai. Salinitas tinggi juga dapat terjadi akibat pelarutan deposit garam di tanah, antara lain $\mathrm{Na}^{+}, \mathrm{K}^{+}, \mathrm{Ca}^{2+}, \mathrm{Mg}^{2+}$, dan $\mathrm{Cl}^{-}$(Kim et al., 2016; Machado \& Serralheiro, 2017).

Salinitas tanah, khususnya yang disebabkan oleh $\mathrm{NaCl}$ merupakan salah satu cekaman abiotik terkait tanah yang paling luas di dunia (Golldack et al., 2014; Lauchli \& Grattan, 2007; Negrao et al., 2017). Beberapa efek negatif dari salinitas antara lain penurunan pertumbuhan (Batool et al., 2014; Machado \& Serralheiro, 2017; Hanin et al., 2016), menekan perluasan daun yang kemudian akan menurunkan laju fotosintesis dan produksi biomassa tanaman (Magdy \& Mansour, 2016). Tumbuhan yang toleran terhadap kadar
$\mathrm{NaCl}$ menerapkan serangkaian adaptasi untuk menyesuaikan diri terhadap salinitas tinggi, termasuk perubahan morfologis, fisiologis dan biokimia (Acosta-Motos et al., 2017). Efek berbahaya dari salinitas dapat bervariasi tergantung pada kondisi iklim, intensitas cahaya, spesies tanaman ataupun kondisi tanah (Tang et al., 2015).

Genangan adalah kondisi ketika tanah mengalami saturasi dan terdapat lapisan air di permukaan tanah (El-Nashar, 2013). Secara alami, genangan dapat terjadi bersamaan atau setelah banjir, namun pada berbagai area terjadinya genangan tidak berhubungan langsung dengan banjir. Genangan dapat terjadi melalui naiknya permukaan air tanah akibat intrusi dari badan - badan air di sekitarnya seperti sungai, danau, dan laut. Berbeda dengan banjir, air pada kondisi genangan relatif tenang dan tidak bergerak secara horizontal. Tanah dikatakan mengalami genangan bila $<10 \%$ pori makronya terisi oleh air (Shaw, 2015).

Adanya lapisan air yang membatasi pertukaran gas antara rhizosfer dan atmosfer memiliki dampak yang besar terhadap tanaman. Terbatasnya laju difusi menyebabkan terjadinya kompetisi penyerapan $\mathrm{O}_{2}$ antara mikroorganisme dan akar tanaman.

Kondisi tergenang menurunkan ketersediaan dan serapan unsur hara (ElNashar, 2013), terjadi akumulasi $\mathrm{CO}_{2}$ hasil respirasi dan fermentasi yang tidak dapat dilepaskan ke atmosfer. Hormon tanaman 
berupa gas (etilen) juga mengalami akumulasi di perakaran tanaman karena tidak dapat dilepaskan ke rizosfer (Salazar et al., 2015; Voesenek \& Bailey-Serres, 2015). Kondisi hipoksia pada rizosfer tidak hanya menyebabkan cekaman pada sistem perakaran karena hilangnya kemampuan untuk menyerap $\mathrm{O}_{2}$, air, dan nutrisi, namun juga dapat menarik $\mathrm{O}_{2}$ keluar dari jaringan akar akibat perbedaan konsentrasi (Kim et al., 2016). Efek negatif yang disebabkan oleh genangan tergantung dari beberapa faktor, antara lain suhu, bahan organik, salinitas, keasaman tanah, dan fase pertumbuhan tanaman (Lauchli \& Grattan, 2007; Negrao et al., 2017).

Salinitas tinggi dan genangan pada lahan kelapa sawit dapat terjadi pada tempat dan waktu yang sama. Sumber genangan yang berasal dari intrusi air laut atau pelarutan deposit garam pada tanah merupakan sumber salinisasi genangan. Interaksi antara salinitas tinggi dan genangan terhadap pertumbuhan kelapa sawit belum banyak diketahui. Penelitian ini bertujuan untuk mengetahui interaksi antara salinitas tinggi dan genangan terhadap pertumbuhan, perubahan morfologis, dan anatomis kelapa sawit.

\section{BAHAN DAN METODE}

Penelitian dilaksanakan pada bulan Maret - September 2017 di dalam rumah kawat yang beratap plastik yang berlokasi di Kebun Penelitian dan Percobaan (KP2) Institut Pertanian Stiper Yogyakarta pada ketinggian $118 \mathrm{~m}$ di atas permukaan laut (dpl), dengan suhu rata-rata $31^{\circ} \mathrm{C}$ dan kelembapan nisbi (Relative Humidity, RH) $70 \%$.
Kecambah kelapa sawit DxP Simalungun yang diperoleh dari Pusat Penelitian Kelapa Sawit (PPKS) Medan ditanam di polybag selama 4 bulan. Kelapa sawit berumur 4 bulan yang memiliki performa visual pertumbuhan yang seragam digunakan sebagai bahan penelitian.

Penelitian ini menggunakan rancangan acak lengkap faktorial. Faktor pertama adalah tingkat salinitas, terdiri dari 2 aras; non salin $\left(0,3 \mathrm{dS} \mathrm{m}^{-1}\right)$ dan salin $\left(4,9 \mathrm{dS} \mathrm{m}^{-1}\right)$. Faktor kedua adalah genangan terdiri dari tiga aras; tanpa genangan, interval genangan 2 minggu (berselang seling 2 minggu tergenang dan 2 minggu tidak tergenang), dan interval genangan 4 minggu (berselang seling 4 minggu tergenang dan 2 minggu tidak tergenang). Masing-masing kombinasi dari kedua faktor tersebut diulang lima kali sehingga diperoleh 30 satuan percobaan. Penelitian diakhiri setelah tanaman mengalami perlakuan selama 4 bulan (tanaman berumur 8 bulan).

Bibit berumur 4 bulan di pembibitan awal (pre nursery) yang memiliki keseragaman performa visual (jumlah daun $11 \pm 1$ helai tinggi tanaman $55 \pm 4 \mathrm{~cm}$ ) dipindahkan ke media tanam baru pada polybag kapasitas $0,075 \mathrm{~m}^{3}$. Tanah yang digunakan sebagai media tanam adalah Regosol. Hasil analisis terhadap sifat fisika, kimia, dan biologi media tanam disajikan pada Tabel 1.

Perlakuan dimulai 2 minggu sejak pindah tanam selama 4 bulan. Pelaksanaan masing - masing faktor adalah sebagai berikut:

- Non salin: daya hantar listrik (electric conductivity, EC) larutan dijaga pada nilai $0,3 \pm 0,2 \mathrm{dS} \mathrm{m}^{-1}$.

- Salin: media tanam disiram dengan larutan $\mathrm{NaCl}$ yang memiliki daya hantar

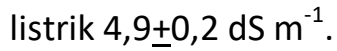


- Tanpa genangan: kandungan air media tanam dijaga pada kapasitas lapang (field capacity).

- Genangan: polybag diletakkan pada ember dan digenangi air sesuai tingkat salinitas yang diujikan hingga ketinggian $10 \mathrm{~cm}$ di atas permukaan media tanam (Gambar 1)

Tabel 1 Sifat fisika dan kimia Regosol yang digunakan sebagai media tanam

\begin{tabular}{|c|c|c|}
\hline Parameter & Nilai & Deskripsi \\
\hline \multicolumn{3}{|l|}{ Sifat fisika } \\
\hline \multicolumn{3}{|c|}{ - Tekstur (Lempung berpasir) } \\
\hline Pasir (\%) & 61,10 & \\
\hline Debu (\%) & 23,23 & \\
\hline Lempung (\%) & 15,67 & \\
\hline - Porositas (\%) & 37,91 & \\
\hline \multicolumn{3}{|l|}{ - Kandungan air (\%) } \\
\hline Asli & 15,37 & \\
\hline Diameter 0,5 mm & 0,61 & \\
\hline diameter $2 \mathrm{~mm}$ & 0,84 & \\
\hline \multicolumn{3}{|c|}{ Sifat kimia } \\
\hline KPK (me $100 \mathrm{~g}^{-1}$ ) & 6,34 & Rendah \\
\hline Bahan organik (\%) & 1,74 & Rendah \\
\hline C-Organik (\%) & 0,97 & Rendah \\
\hline $\mathrm{pH} \mathrm{H}_{2} \mathrm{O}$ & 6,59 & Netral \\
\hline $\mathrm{N}$-tersedia (ppm) & 80,9 & $\begin{array}{l}\text { Sangat } \\
\text { rendah }\end{array}$ \\
\hline EC larutan (dS m $\left.{ }^{-1}\right)$ & 0,26 & Rendah \\
\hline
\end{tabular}

Pertumbuhan vegetatif diukur dengan melakukan pengamatan pada berat segar akar dan tajuk; berat kering akar dan tajuk; luas daun; luas, volume, dan panjang total akar. Analisis anatomi dilakukan dengan membuat potongan melintang pada akar primer, sekunder, dan tersier menggunakan mikrotom YD-202A (Karya Mitra Mulia, Indonesia) dengan ketebalan $10 \mu \mathrm{m}$.

Preparat diamati menggunakan mikroskop perbesaran 100 dan 400 kali, kemudian gambar ditangkap menggunakan OptiLab Advance (Optilab LLC., Phoenix). Dilakukan pengamatan terhadap luas jaringan epidermis, korteks, endodermis, dan stele akar primer, sekunder, dan tersier menggunakan perangkat lunak Digam ver. 1.0 dan Micam ver. 2.0.

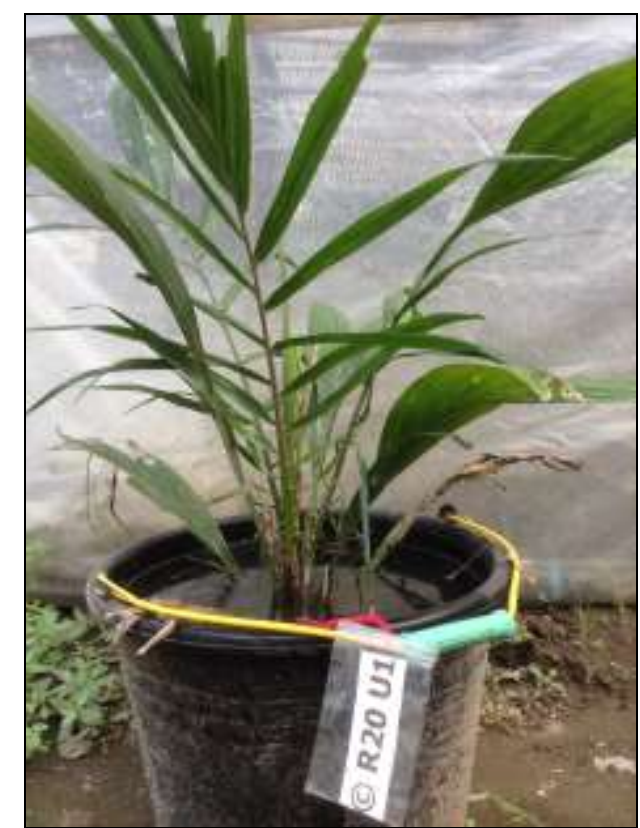

Gambar 1. Perlakuan genangan pada media tanam

Berat segar masing-masing bagian tanaman diukur menggunakan neraca analitik pada tingkat ketelitian $1 \mathrm{mg}$. Berat kering diukur dengan terlebih dahulu mengeringkan bagian tanaman menggunakan oven pada suhu $70{ }^{\circ} \mathrm{C}$ hingga mencapai berat konstan. Luas daun dan akar dan panjang total akar diukur menggunakan area meter sebelum dikeringkan. Volume akar diukur dengan mencelupkan akar dalam gelas ukur dan menghitung selisih ketinggian airnya.

Data pengamatan dianalisis sidik ragam (analysis of variance, Anova) dan uji jarak berganda Duncan (Duncan's Multiple range test, DMRT) pada jenjang nyata $5 \%$ $(P \leq 0,05)$ menggunakan perangkat lunak statistik IBM $^{\circledR}$ SPSS $^{\circledR}$ Statistic v. 23 (IBM Corporation, Chicago, IL). 


\section{HASIL DAN PEMBAHASAN}

\section{Pertumbuhan vegetatif}

Salinitas tinggi menurunkan semua parameter pertumbuhan kelapa sawit yang diamati, baik pertumbuhan tajuk (Tabel 2) maupun akar (Tabel 3). Genangan 2 minggu memberikan pengaruh negatif terendah, diikuti genangan 4 minggu dan tanpa genangan. Genangan non salin 2 minggu tidak berpengaruh nyata terhadap berat segar akar, panjang akar, dan luas daun, sementara durasi genangan 4 minggu menurunkan semua parameter pertumbuhan tajuk dan pertumbuhan akar tanaman yang diamati. Akumulasi fotosintat yang ditunjukkan melalui pengamatan terhadap berat kering total (akar + tajuk) pada kondisi genangan non salin 2 minggu, 4 minggu, salinitas tinggi tanpa genangan, genangan salin 2 minggu, dan genangan salin 4 minggu mengalami penurunan masing - masing sebesar 19\%, 65\%, 137\%, $146 \%$, dan $130 \%$ dibandingkan perlakuan non salin tanpa genangan.

Tabel 2. Pertumbuhan tajuk kelapa sawit

\begin{tabular}{llccc}
\hline & & \multicolumn{3}{c}{ Parameter pertumbuhan } \\
\cline { 3 - 5 } & Perlakuan & Luas daun $\left(\mathrm{cm}^{2}\right)$ & $\begin{array}{c}\text { Berat segar } \\
\text { tajuk }(\mathrm{g})\end{array}$ & $\begin{array}{c}\text { Berat kering } \\
\text { tajuk }(\mathrm{g})\end{array}$ \\
\hline \multirow{2}{*}{ Non salin } & Tidak tergenang & $6,533 \mathrm{a}$ & $155 \mathrm{a}$ & $34 \mathrm{a}$ \\
& Genangan 2 minggu & $6,093 \mathrm{a}$ & $123 \mathrm{~b}$ & $27 \mathrm{~b}$ \\
& Genangan 4 minggu & $5,095 \mathrm{~b}$ & $96 \mathrm{c}$ & $15 \mathrm{c}$ \\
\hline Salin & Tidak tergenang & $2,851 \mathrm{~d}$ & $43 \mathrm{e}$ & $10 \mathrm{c}$ \\
& Genangan 2 minggu & $4,447 \mathrm{bc}$ & $70 \mathrm{~d}$ & $15 \mathrm{c}$ \\
& Genangan 4 minggu & $3,851 \mathrm{c}$ & $58 \mathrm{de}$ & $10 \mathrm{c}$
\end{tabular}

Keterangan : angka yang diikuti huruf yang sama pada kolom menunjukkan tidak berbeda nyata pada tingkat kepercayaan 95\% berdasarkan uji jarak berganda Duncan

Kelapa sawit mampu beradaptasi pada kondisi muka air tanah yang tinggi, namun tidak toleran terhadap genangan terus menerus (Rivera-Mendes et al., 2016). Kelapa sawit memiliki toleransi lebih lama ketika berada pada genangan air yang mengalir dibandingkan air yang stagnan (Koon \& Kun, 2006). Genangan non salin selama dua minggu diduga masih berada pada kisaran toleransi kelapa sawit, dibuktikan dengan tidak berubahnya beberapa parameter pertumbuhan penting secara signifikan, seperti luas daun dan panjang akar. Nisbah akar tajuk juga tidak mengalami perubahan signifikan pada genangan dua minggu. Penurunan yang signifikan pada seluruh parameter pertumbuhan terjadi pada durasi genangan empat minggu (Tabel 2).
Perbedaan salinitas memberikan selisih pertumbuhan vegetatif lebih besar dibandingkan durasi genangan. Penurunan pertumbuhan tertinggi yang ditunjukkan oleh akumulasi berat kering akar dan tajuk terjadi pada perlakuan salin tanpa genangan yaitu $59,73 \%$, diikuti genangan salin 4 minggu (48,94\%), genangan salin 2 minggu $(40,25 \%)$, genangan non salin 4 minggu $(34,38 \%)$, dan genangan non salin 2 minggu $(14,36 \%)$ dibandingkan kontrol (non salin tanpa genangan).

Penurunan pertumbuhan yang dicerminkan melalui rendahnya akumulasi biomassa pada kondisi salin di semua rezim air dibandingkan kontrol (non salin tanpa genangan) menunjukkan bahwa tanaman 
mengalami cekaman (Tabel 2 dan Tabel 3). Masuknya ion natrium dan klorida ke tubuh tanaman melalui mekanisme pasif (aliran massa) dan aktif (pompa ion $\mathrm{Na}^{+} / \mathrm{K}^{+}$) (Fakhrfeshani et al., 2015). Endodermis berperang penting dalam mengatur transpor ion secara radial dari larutan tanah menuju xilem akar, hal ini karena pita caspari bersifat impermeable sehingga mencegah terjadinya pergerakan larutan secara apoplastik (Chen et al., 2011).

Daun adalah organ fotosintesis utama pada sebagian besar tanaman, termasuk kelapa sawit. Karbohidrat yang dibentuk selama fotosintesis merupakan sumber energi utama bagi pertumbuhan dan perkembangan tanaman. Genangan non salin selama 2 minggu tidak berpengaruh nyata terhadap luas daun (Tabel 2). Luas daun pada seluruh kombinasi salinitas dan genangan mengalami penurunan dibanding kontrol (non salin tanpa genangan).

Pengaruh kerusakan daun, kegagalan penyerapan air dan nutrisi yang cukup, serta penutupan stomata berkontribusi langsung terhadap rendahnya akumulasi fotosintat pada kondisi salin (Firmansyah et al., 2016; 2017). Secara visual, kerusakan ini umumnya ditandai dengan terbakarnya ujung dan tepi daun, klorosis (daun menguning), nekrosis, dan kerontokan dini daun (Jaleel et al., 2009). Tingkat keparahan yang ditimbulkan oleh salinitas tinggi berbeda pada berbagai rezim air.

Salinitas tinggi tanpa genangan mengalami penurunan luas daun terbesar yaitu $56,4 \%$, diikuti genangan salin 4 minggu (41,0\%), genangan salin 2 minggu (31,9\%), genangan non salin 4 minggu $(22,0 \%)$, dan genangan non salin 2 minggu (6,7\%). Penurunan akumulasi biomassa yang merupakan produk dari fotosintesis yang digambarkan dengan berat kering akar dan tajuk sangat dipengaruhi oleh luas daun, masing - masing sebesar $76,7 \%$ dan $70,4 \%$.

Salinitas tinggi menyebabkan kerusakan pigmen fotosintesis pada daun, ditunjukkan warna daun berubah dari hijau menjadi hitam dan rapuh (Jaleel et al., 2009). Pengaruh toksin dari sodium dan klorida merupakan penyebab kerusakan daun, dimana kedua unsur tersebut menyebabkan disintegrasi membran sel (Lauchli \& Grattan, 2007; Jamil et al., 2012; Negrao et al., 2017).

Tabel 3. Pertumbuhan akar kelapa sawit

\begin{tabular}{llccccc}
\hline & & \multicolumn{4}{c}{ Parameter pertumbuhan } \\
\cline { 3 - 7 } & Perlakuan & $\begin{array}{c}\text { Berat segar } \\
\text { akar }(\mathrm{g})\end{array}$ & $\begin{array}{c}\text { Berat } \\
\text { kering } \\
\text { akar }(\mathrm{g})\end{array}$ & $\begin{array}{c}\text { Luas akar } \\
\left(\mathrm{cm}^{2}\right)\end{array}$ & $\begin{array}{c}\text { Volume } \\
\text { akar }\left(\mathrm{cm}^{3}\right)\end{array}$ & $\begin{array}{c}\text { Panjang total } \\
\text { akar }(\mathrm{cm})\end{array}$ \\
\hline Non salin & Tidak tergenang & $65 \mathrm{a}$ & $21 \mathrm{a}$ & $11,564 \mathrm{a}$ & $77 \mathrm{a}$ & $2,932 \mathrm{a}$ \\
& Genangan 2 minggu & $56 \mathrm{a}$ & $18 \mathrm{~b}$ & $10,324 \mathrm{~b}$ & $63 \mathrm{~b}$ & $2,642 \mathrm{a}$ \\
& Genangan 4 minggu & $44 \mathrm{~b}$ & $11 \mathrm{~cd}$ & $9,154 \mathrm{c}$ & $48 \mathrm{~cd}$ & $2,326 \mathrm{ab}$ \\
\hline Salin & Tidak tergenang & $18 \mathrm{~d}$ & $9 \mathrm{e}$ & $6,921 \mathrm{e}$ & $38 \mathrm{~d}$ & $1,220 \mathrm{c}$ \\
& Genangan 2 minggu & $34 \mathrm{bc}$ & $12 \mathrm{c}$ & $8,668 \mathrm{~cd}$ & $54 \mathrm{bc}$ & $1,939 \mathrm{~b}$ \\
& Genangan 4 minggu & $27 \mathrm{~cd}$ & $10 \mathrm{de}$ & $7,987 \mathrm{de}$ & $52 \mathrm{bc}$ & $1,669 \mathrm{bc}$ \\
\hline
\end{tabular}

Keterangan : Angka yang diikuti huruf yang sama pada kolom menunjukkan tidak berbeda nyata pada tingkat kepercayaan 95\% berdasarkan uji jarak berganda Duncan 
Salinitas tinggi menurunkan penyerapan air dan nutrisi, antara lain kalsium dan kalium. Salah satu fungsi kalsium adalah mempertahankan integritas membran (Jamil et al., 2012). Penurunan serapan kalsium disebabkan meningkatnya rasio $\mathrm{Na}^{+} / \mathrm{Ca}^{2+}$, yang juga berkontribusi menurunkan pertumbuhan akar (Munns, 2002; Firmansyah et al., 2016; Machado \& Serralheiro, 2017). Konsentrasi $\mathrm{K}^{+}$pada jaringan tanaman terbukti mengalami penurunan ketika terpapar oleh cekaman salin (Morales et al., 2012). Rendahnya $\mathrm{K}^{+}$ merupakan akibat dari hambatan penyerapannya oleh tingginya $\mathrm{Na}^{+}$(Gupta \& Huang, 2014; Fakhrfeshani et al., 2015). Natrium menyebabkan penurunan jumlah pigmen fotosintesis akibat rendahnya pembentukan dan kerusakan klorofil. Kandungan klorofil pada tanaman yang mengalami cekaman salin merupakan fungsi dari kandungan natrium daun. Penurunan kandungan klorofil disebabkan oleh peningkatan aktivitas enzim chlorophyllase (Jaleel et al., 2009).

Tantangan yang dihadapi tanaman pada kondisi salin adalah tanaman harus tetap menyerap nutrisi dan mencegah masuknya ion toksin, sementara potensial air lebih rendah dari kondisi non salin (Li et al., 2015; Duarte \& Souza, 2016; Foster \& Miklavcic, 2017). Efek cekaman yang ditimbulkan oleh salinitas tinggi dapat dibagi menjadi dua, yaitu efek jangka pendek dan jangka panjang (Jouyban, 2012). Efek jangka pendek melibatkan penurunan pertumbuhan tajuk (Tabel 2), diduga akibat respon akar terhadap defisit air. Efek jangka panjang terjadi dalam hitungan beberapa minggu paparan yang menyebabkan penyerapan dan penumpukan ion garam pada organ tanaman terutama pada akar dan daun.
Durasi genangan non salin yang berbeda tidak memberikan pengaruh yang nyata terhadap pemanjangan akar, namun kondisi salin menyebabkan penurunan panjang akar, terutama pada perlakuan tanpa genangan. Hasil ini tidak berkorelasi positif dengan luas akar dan volume akar, dimana genangan non salin menyebabkan penurunan yang signifikan terhadap kedua parameter tersebut meskipun genangan salin selama 2 dan 4 minggu tidak menunjukkan perbedaan yang nyata.

Pada kondisi non salin, genangan dua minggu tidak memberikan pengaruh negatif yang berarti terhadap panjang akar (Tabel 2) dan luas daun (Tabel 3), namun telah menyebabkan penurunan akumulasi fotosintat. Kelapa sawit memiliki toleransi terhadap genangan dalam jangka waktu terbatas (Rivera-Mendes et al., 2016). Genangan yang lebih lama dari toleransi menyebabkan cekaman terhadap kelapa sawit. Gejala pertama muncul pada daun, antara lain busuk disepanjang tulang daun dan pembusukan di pangkal pelepah. Adapun pada kondisi salin, genangan konsisten menurunkan semua parameter pertumbuhan.

Genangan merupakan kondisi dimana jumlah air berlebih pada zona perakaran menyebabkan hambatan pertukaran gas dengan atmosfer (Jamil et al., 2012) . Secara umum difusi gas pada kondisi tergenang 10.000 kali lebih lambat dibandingkan di udara (Rivera-Mendes et al., 2016). Genangan menyebabkan berbagai pengaruh sekunder seperti perubahan elektrokimia, akumulasi pemecahan produk dari bahan organik sebagaimana telah dibahas oleh Ponnamperuma (1972).

Rendahnya kandungan $\mathrm{O}_{2}$ memicu efek negatif dari genangan terhadap pertumbuhan tanaman. Genangan dengan 
tingkat salinitas berbeda memiliki tingkat pertumbuhan yang berbeda. Peningkatan salinitas di semua rezim air diikuti penurunan semua parameter pertumbuhan. Durasi genangan yang sama pada kondisi salin memberikan pertumbuhan yang lebih rendah dibandingkan non salin. Genangan mengurangi penyerapan nutrisi yang berujung pada perbedaan konsentrasi nutrisi di bagian tanaman yang berbeda (Jamil et al., 2012). Defisiensi oksigen menyebabkan penurunan selektivitas penyerapan $\mathrm{Na}^{+} / \mathrm{K}^{+}$yang menekan transport $\mathrm{K}^{+}$menuju tajuk (Fakhrfeshani et al., 2015). Meskipun demikian, menurut beberapa literatur (Koon \& Kun, 2006; Henson et al., 2008; Jamil et al., 2012; Rivera-Mendes et al., 2016) pengaruh negatif genangan yang terkait nutrisi bukan merupakan akibat toksisitas ion $\mathrm{Na}^{+}$, tetapi akibat dari menurunnya konsentrasi $\mathrm{N}, \mathrm{P}, \mathrm{K}, \mathrm{Ca}$, dan Mg.

\section{Perubahan morfologis dan anatomis akar}

Perbedaan pengurangan pertumbuhan tanaman pada tingkat salinitas dan rezim air yang berbeda merupakan dampak beberapa penyesuaian morfologis dan anatomis. Analisis terhadap parameter pertumbuhan kelapa sawit menunjukkan adanya hubungan sinergis kompensatif antara salinitas tinggi dan genangan pada durasi tertentu. Salinitas tinggi yang diikuti dengan genangan terbukti menurunkan efek negatif yang disebabkan oleh $\mathrm{Na}^{+}$dan $\mathrm{Cl}^{-}$.

Pada kondisi salin, genangan empat minggu memberikan pertumbuhan yang tidak berbeda nyata dengan genangan dua minggu, ditunjukkan dengan berat kering tajuk (Tabel 2) dan berat kering akar (Tabel 3). Dapat diduga bahwa genangan dua dan empat minggu secara langsung atau tidak langsung menekan pengaruh negatif salinitas tinggi. Hal ini berbeda dengan temuan Parent et al. (2008) yang menyatakan bahwa genangan meningkatkan penyerapan garam pada kondisi salin. Meskipun demikian, Shannon (1997) menyatakan bahwa tanggapan tanaman terhadap kondisi salin dapat berbeda pada rezim air yang berbeda.

\section{Morfologis akar}

Perubahan jumlah dan tingkat salinitas air dalam media tanam memberikan pengaruh yang besar terhadap fisiologis, morfologis, dan anatomis akar kelapa sawit. Kelapa sawit merupakan tanaman yang memiliki toleransi terhadap genangan pada jangka waktu tertentu (Corley \& Tinker, 2015). Kelapa sawit mengembangkan perakaran epigeal yang tumbuh melawan gravitasi (negative geotropism), disebut pneumatophore. Akar ini tumbuh memanjang hingga mencapai permukaan air dan pertumbuhannya terhenti ketika telah mencapai ketinggian $\pm 1 \mathrm{~cm}$ dari permukaan air (Gambar 2).

Pneumatophore terbentuk pada tanaman yang mengalami genangan lebih dari 10 hari. Perubahan morfologis akar ini merupakan mekanisme adaptasi terhadap kondisi hipoksia pada perakaran (Corley \& Tinker, 2015), Genangan non salin yang hanya menghadapi cekaman tunggal mampu mengembangkan pneumatophore lebih dahulu dibandingkan genangan salin, yang menghadapi cekaman ganda. Kompleksitas cekaman yang dihadapi suatu tanaman mempengaruhi alokasi energi yang digunakannya untuk menghadapi cekaman tersebut (Jenks \& Hasegawa, 2007).

Pneumatophore mulai muncul setelah tanaman mengalami rendaman selama 1015 hari. Waktu munculnya pneumatophore berbeda antara perlakuan genangan non 
salin dan salin. Genangan salin menyebabkan tanaman membentuk pneumatophore 3-4 hari lebih cepat dibandingkan dengan genangan non salin.

Pada akhir penelitian diketahui bahwa tanaman yang mengalami durasi genangan dan tingkat salinitas berbeda membentuk pneumatophore dengan jumlah yang tidak sama. Kelapa sawit yang berada pada kondisi tergenang membentuk 14 - 60 pneumatophore. Tanaman yang mengalami genangan 4 minggu memiliki pneumatophore yang lebih banyak dibandingkan tanaman yang mengalami genangan 2 minggu. Pneumatophore pada tanaman yang mengalami genangan salin lebih sedikit dibandingkan genangan non salin. Jumlah Pneumatophore yang paling sedikit terbentuk pada genangan salin 2 minggu, sementara yang terbanyak pada genangan non salin selama 4 minggu.

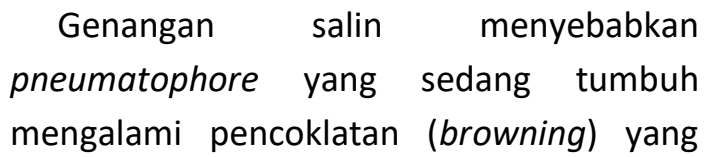
diikuti oleh kerusakan atau kematian akar. Pneumatophore yang terpapar udara bebas ketika dilakukan pengatusan air menunjukkan perubahan warna dari putih menjadi kuning kecoklatan. Pneumatophore ini bertahan hingga tanaman mengalami genangan pada interval berikutnya, namun warnanya tidak kembali menjadi putih sebagaimana pada genangan interval sebelumnya.

Pneumatophore yang mampu mencapai permukaan air memiliki panjang bervariasi antara $1-12 \mathrm{~cm}$, bergantung pada letak tumbuhnya. Struktur akar yang khas ini muncul dari akar primer pada jarak $<0,1-$ $15 \mathrm{~cm}$ dari pangkal batang, sehingga dapat disebut sebagai modifikasi akar sekunder.

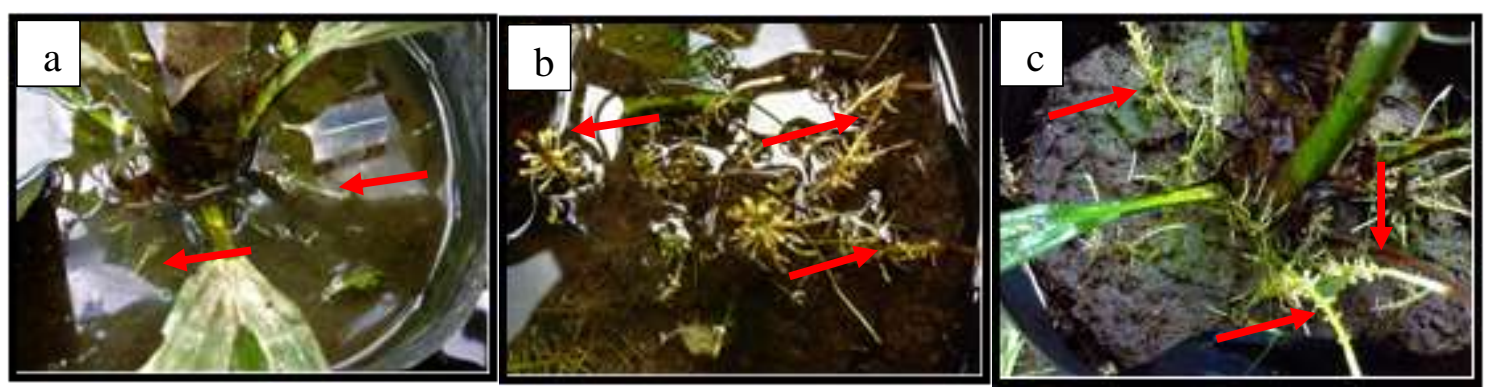

Gambar 2. Kemunculan pneumatophore kelapa sawit yang tumbuh pada kondisi tergenang; a. kemunculan awal pneumatophore pada hari ke-10 pasca genangan diawali dari pangkal batang; b. Pneumatophore yang tumbuh pada kondisi genangan salin menunjukkan terjadinya pencoklatan (browning); c. pengatusan air genangan menunjukkan arah pertumbuhan pneumatophore yang geotropism negatif.

Secara visual pneumatophore berada pada jarak kurang dari $15 \mathrm{~cm}$ dari batang kelapa sawit. Pneumatophore kelapa sawit memiliki percabangan (akar tersier) yang dominan berada pada bagian pangkal akar $(<5 \mathrm{~cm})$ dan ujungnya berbentuk tudung melebar. Percabangan akar ini memiliki arah pertumbuhan yang tegak lurus ke segala arah dari akar sekunder. Akar tersier yang muncul dari pneumatophore memiliki panjang $<4 \mathrm{~cm}$, pendek pada pangkal semakin memanjang kemudian memendek lagi saat mendekati ujung.

Potongan melintang pada jarak $2 \pm 0,2 \mathrm{~cm}$ dari pangkal menunjukkan bahwa pneumatophore memiliki diameter rata-rata $1,1 \mathrm{~cm}$. Sebagaimana percabangan akar yang lain, pneumatophore muncul dari stele 
akar primer (Gambar 3). Pneumatophore membentuk struktur aerenkima yang merupakan modifikasi korteks akar.

Laju difusi oksigen di air lebih rendah $10^{-5}$ kali dibandingkan di udara (Wegner, 2010). Rendahnya konsentrasi oksigen ini menyebabkan kerusakan pada ujung akar yang telah berkembang sebelum terjadinya genangan, dan menekan pertumbuhan akar baru. Dampak kondisi ini adalah terhambatnya pertumbuhan dan perkembangan. Pada tanaman yang tidak toleran, jika kondisi tersebut berlanjut dalam durasi lama maka akan menyebabkan kematian.

Terbentuknya pneumatophore pada kondisi genangan memungkinkan kelapa sawit memperoleh pasokan oksigen tidak hanya melalui stomata yang ada pada daun dan pelepah namun juga melalui lentisel (Jackson \& Colmer, 2005). Lentisel pneumatophore terletak pada ujung akar yang muncul di permukaan air, dimana pada bagian ini dinding sel akar mempunyai lapisan suberin dan terus menyebar ke arah pangkal pneumatophore yang memiliki lebih sedikit lapisan suberin (Rivera-Mendes et al., 2016).

Berbeda dengan stomata yang memiliki mekanisme buka-tutup menyesuaikan dengan status air internal tananam, lentisel bersifat pasif dan selalu dapat dilalui oleh $\mathrm{O}_{2}$. Masuknya oksigen melalui lentisel dikendalikan oleh gradien konsentrasi $\mathrm{O}_{2}$ internal dan eksternal tanaman (Wegner, 2010). Oksigen yang masuk melalui lentisel diduga dapat mengkompensasi penurunan suplai oksigen melalui stomata. Suplai oksigen melalui pneumatophore dapat segera terdistribusi menuju seluruh bagian tanaman terutama akar karena jaraknya yang dekat dengan akar utama sawit mengingat pneumatophore tumbuh pada lokasi sebagaimana akar sekunder.

\section{Anatomis Akar}

Pengukuran terhadap luas jaringan epidermis, korteks, endodermis, dan stele terhadap akar primer (Tabel 4), sekunder (Tabel 5), dan tersier (Tabel 6) menunjukkan adanya perubahan struktur dan luas masing-masing jaringan tersebut pada rezim air dan salinitas yang berbeda. Luas jaringan korteks, endodermis, dan stele mengalami tekanan terbesar pada perlakuan salinitas tinggi tanpa genangan, sementara luas jaringan epidermis mengalami tekanan terbesar pada genangan non salin 4 minggu.

Pada durasi genangan 2 dan 4 minggu, kondisi salin menyebabkan kelapa sawit memiliki epidermis akar primer, sekunder, dan tersier yang lebih luas masing-masing $2 \%, 18 \%$, dan $13 \%$ dibandingkan non salin. Salinitas tinggi pada genangan 2 dan 4 minggu juga menyebabkan penurunan luas korteks, endodermis, dan stele pada semua tipe akar antara 14,5 - 49,6\%. Stele mengalami penurunan terbesar, diikuti endodermis dan korteks dibandingkan non salin, kecuali luas stele akar tersier.

Genangan pada semua tingkat salinitas menyebabkan penurunan luas epidermis pada semua tipe akar, baik pada rendaman 2 minggu maupun 4 minggu dibandingkan tanpa genangan. Luas epidermis akar primer, sekunder, dan tersier masing masing mengalami penurunan $7,75 \%$, $14,70 \%$, dan $6,83 \%$ pada durasi genangan 2 minggu dibandingkan tanpa genangan. Genangan 4 minggu menurunkan luas epidermis akar primer, sekunder, dan tersier masing - masing $12,36 \%, 21,52 \%$, dan $19,63 \%$ dibandingkan tanpa genangan. Genangan 2 minggu meningkatkan luas korteks, endodermis, dan stele akar primer 
dan sekunder antara 0,4-12,6\%. Genangan 4 minggu menurunkan luas korteks, endodermis, dan stele seluruh tipe akar dengan besar penurunan antara 1,47 $31,88 \%$ dibandingkan tanpa genangan.

Tabel 4. Anatomis akar primer kelapa sawit

\begin{tabular}{|c|c|c|c|c|c|}
\hline & \multirow{2}{*}{ Perlakuan } & \multicolumn{4}{|c|}{ Luas ( $\mu \mathrm{m})$} \\
\hline & & Epidermis & Korteks & Endodermis & Stele \\
\hline \multirow[t]{3}{*}{ Non salin } & Tidak tergenang & $2.665 \mathrm{~b}$ & $11.546 \mathrm{a}$ & $5.442 \mathrm{a}$ & $9.118 \mathrm{a}$ \\
\hline & Genangan 2 minggu & $2.598 b$ & $11.189 \mathrm{ab}$ & $5.061 \mathrm{a}$ & $9.014 \mathrm{a}$ \\
\hline & Genangan 4 minggu & $2.282 \mathrm{~d}$ & $10.317 \mathrm{bc}$ & $4.401 b$ & $5.571 \mathrm{bc}$ \\
\hline \multirow[t]{3}{*}{ Salin } & Tidak tergenang & $2.772 \mathrm{a}$ & $8.235 \mathrm{e}$ & $3.208 \mathrm{c}$ & $5.297 \mathrm{c}$ \\
\hline & Genangan 2 minggu & $2.448 \mathrm{c}$ & $9.395 \mathrm{~cd}$ & $4.389 \mathrm{~b}$ & $6.170 \mathrm{~b}$ \\
\hline & Genangan 4 minggu & $2.483 \mathrm{c}$ & $8.884 \mathrm{de}$ & $3.951 \mathrm{c}$ & $5.525 \mathrm{bc}$ \\
\hline
\end{tabular}

Keterangan : angka yang diikuti huruf yang sama pada kolom menunjukkan tidak berbeda nyata pada tingkat kepercayaan $95 \%$ berdasarkan uji jarak berganda Duncan

Tabel 5. Anatomis akar sekunder kelapa sawit

\begin{tabular}{|c|c|c|c|c|c|}
\hline & \multirow{2}{*}{ Perlakuan } & \multicolumn{4}{|c|}{ Luas ( $\mu \mathrm{m})$} \\
\hline & & Epidermis & Korteks & Endodermis & Stele \\
\hline \multirow[t]{3}{*}{ Non salin } & Tidak tergenang & $1.975 \mathrm{a}$ & $5.032 \mathrm{a}$ & 789 a & $490 \mathrm{a}$ \\
\hline & Genangan 2 minggu & $1.875 \mathrm{a}$ & $4.838 \mathrm{a}$ & $711 \mathrm{~b}$ & $470 \mathrm{a}$ \\
\hline & Genangan 4 minggu & $1.573 \mathrm{a}$ & $4.778 \mathrm{a}$ & $658 b$ & $238 c$ \\
\hline \multirow[t]{3}{*}{ Salin } & Tidak tergenang & $2.574 \mathrm{a}$ & $3.511 \mathrm{a}$ & $447 \mathrm{e}$ & $222 \mathrm{c}$ \\
\hline & Genangan 2 minggu & $2.091 \mathrm{a}$ & $3.735 a$ & $588 \mathrm{c}$ & $332 b$ \\
\hline & Genangan 4 minggu & $1.997 \mathrm{a}$ & $4.010 \mathrm{a}$ & $528 d$ & $247 c$ \\
\hline
\end{tabular}

Keterangan : angka yang diikuti huruf yang sama pada kolom menunjukkan tidak berbeda nyata pada tingkat kepercayaan 95\% berdasarkan uji jarak berganda Duncan

Tabel 6. Anatomis akar tersier kelapa sawit

\begin{tabular}{|c|c|c|c|c|c|}
\hline & \multirow{2}{*}{ Perlakuan } & \multicolumn{4}{|c|}{ Luas $(\mu \mathrm{m})$} \\
\hline & & Epidermis & Korteks & Endodermis & Stele \\
\hline \multirow[t]{3}{*}{ Non salin } & Tidak tergenang & $966 a$ & $2.030 \mathrm{a}$ & $79 a$ & $59 a$ \\
\hline & Genangan 2 minggu & 880 a & $1.930 \mathrm{ab}$ & $76 a$ & $54 a$ \\
\hline & Genangan 4 minggu & 768 a & $1.803 \mathrm{bc}$ & $65 b$ & $46 a$ \\
\hline \multirow[t]{3}{*}{ Salin } & Tidak tergenang & $1.067 \mathrm{a}$ & $1.587 \mathrm{e}$ & $43 d$ & $84 a$ \\
\hline & Genangan 2 minggu & $1.023 \mathrm{a}$ & $1.684 \mathrm{de}$ & $57 c$ & $71 \mathrm{a}$ \\
\hline & Genangan 4 minggu & 866 a & $1.761 \mathrm{c}$ & $52 c$ & $61 \mathrm{a}$ \\
\hline
\end{tabular}

Keterangan : angka yang diikuti huruf yang sama pada kolom menunjukkan tidak berbeda nyata pada tingkat kepercayaan 95\% berdasarkan uji jarak berganda Duncan 
Pada kondisi tergenang, epidermis tanaman akan mengalami penebalan internal sehingga mencegah lepasnya $\mathrm{O}_{2} \mathrm{ke}$ lingkungan rizosfer, lebih lanjut penghalang ini dapat menghambat masuknya ion dan gas toksin ke akar (Nishiuchi et al., 2012). Adanya suberin sebagai penghalang tambahan di permukaan luar korteks itu memiliki peran tambahan antara lain bisa melindungi tanaman dari ion toksin seperti $\mathrm{Na}^{+}$dan $\mathrm{Cl}^{-}$serta fitotoksin yang dihasilkan oleh mikroorganisme di sekitar akar (Voesenek \& Bailey-Serres, 2015).

Pengamatan terhadap potongan melintang menunjukkan bahwa terjadi perubahan struktur akar primer, sekunder, dan tersier kelapa sawit pada kondisi genangan baik non salin maupun salin (Gambar 3). Semua tipe akar kelapa sawit tersusun atas jaringan epidermis, korteks, endodermis, dan stele.

Jaringan korteks mengalami peluruhan (lisis) sebagian ketika tanaman mengalami genangan. Peluruhan korteks menyebabkan terbentuknya saluran udara dari batang hingga ke ujung akar. Struktur khas ini disebut aerenkima. Indikasi terbentuknya aerenkima juga diketahui dari jarak antar sel jaringan korteks dan porositas akar. Genangan 4 minggu menyebabkan tanaman membentuk aerenkima lebih banyak dibandingkan genangan 2 minggu (Gambar 3). Pada durasi genangan yang sama, genangan non salin memberikan aerenkima lebih banyak dibandingkan salinitas tinggi.

Saat tanaman terpapar pada lingkungan yang memiliki kandungan air berlebihan maka cekaman yang dialami adalah pengurangan konsentrasi dan laju difusi oksigen pada rizhosfer (Koon \& Kun, 2006; Jamil et al., 2012; Rivera-Mendes et al., 2016). Salah satu tanggapan pertama tanaman pada kondisi tersebut adalah peningkatan resistensi stomata, sehingga pertukaran gas dan penyerapan air menjadi terbatas, menyebabkan terjadinya defisit air internal (Parent et al., 2008). Pada satu sisi kondisi ini membawa konsekuensi negatif, dimana penyerapan nutrisi (unsur hara) dan air menjadi terbatas, sementara keduanya adalah komponen utama yang berpengaruh langsung terhadap pertumbuhan tanaman. Pada sisi yang lain, kondisi ini mampu mengkompensasi kerusakan lebih berat yang disebabkan oleh salinitas tinggi akibat larutan garam berlebih di rhizosfer.

Penurunan konduktansi stomata mencegah ion garam terutama $\mathrm{Na}^{+}$ memasuki akar, sehingga secara tidak langsung genangan mengaktifkan mekanisme ketahanan kelapa sawit terhadap salinitas tinggi melalui penurunan serapan ion tersebut (Gupta \& Huang, 2014). Beberapa penelitian juga melaporkan bahwa kondisi hipoksia menyebabkan penurunan permeabilitas membran akar terhadap $\mathrm{Na}^{+}$(Ashraf, 2012; Parent et al., 2008). Tanaman yang mampu membatasi penyerapan ion toksin dan menjaga konsentrasinya tetap rendah dapat memiliki toleransi yang lebih tinggi dibandingkan tanaman yang menyerap ion lebih banyak.

Kelapa sawit merupakan tanaman mesofit yang hidup pada kondisi perakaran aerob, kondisi tergenang menginduksi terbentuknya saluran aerenkima pada perakarannya. Pembentukan aerenkima (saluran udara di sepanjang akar) merupakan mekanisme adaptasi tanaman yang memungkinkan untuk bertahan selama genangan (Jackson \& Colmer, 2005; Parent et al., 2008; Jamil et al., 2012). Peningkatan porositas dengan adanya aerenkima dapat meningkatkan ventilasi pada bagian atas tanaman dan pengudaraan senyawa beracun yang 
diproduksi di akar (misalnya, etanol dan metana) dan meningkatkan difusi longitudinal gas pada akar sehingga meningkatkan aerasi (Visser \& Pierik, 2007).
Jaringan ini memfasilitasi difusi internal $\mathrm{O}_{2}$ hingga ke ujung akar (Voesenek \& BaileySerres, 2015; Rivera-Mendes et al., 2016).
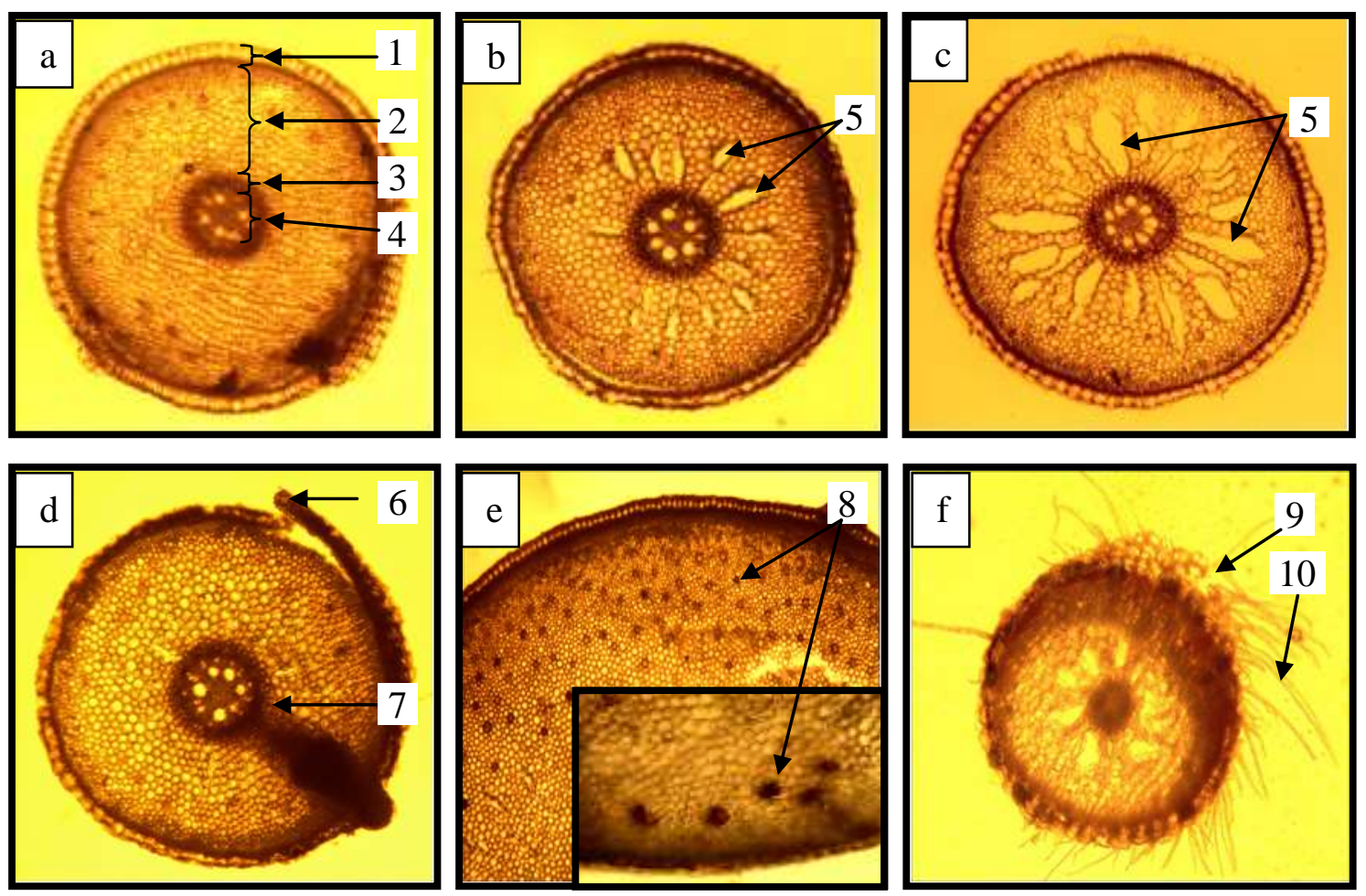

Gambar 3. Penampang melintang perakaran kelapa sawit; a. Akar primer pada perlakuan non salin tanpa genangan (perbesaran 100 kali); b. Akar primer pada perlakuan genangan dua minggu (perbesaran 100 kali); c. Akar primer pada genangan empat minggu (perbesaran 100 kali); d. akar primer pada salinitas tinggi tanpa genangan; e. Akar primer pada salinitas tinggi tanpa genangan (perbesaran 400 kali); f. Pneumatophore; 1 . epidermis; 2. korteks; 3. endodermis; 4. stele; 5. aerenkim; 6. percabangan akar sekunder; 7. kerusakan epidermis akar primer pada kondisi salin tanpa genangan; 8. deposisi Na pada jaringan korteks akar (yang menyebabkan kerusakan berupa reaksi pencoklatan); 9. lentisel; 10. struktur filamen / rambut akar yang merupakan modifikasi epidermis pada ujung pneumatophore.

Meskipun seluruh ahli sepakat tentang adanya jaringan aerenkima, namun berbeda pendapat tentang kriteria jarak antar sel untuk disebut sebagai aerenkima (Nishiuchi et al., 2012). Pengamatan terhadap anatomis akar menunjukkan terbentuknya aerenkima pada kondisi genangan tidak mengubah konfigurasi jaringan penyusun akar lainnya (epidermis, endodermis, dan stele). Hal ini menunjukkan bahwa aerenkima bukan merupakan jaringan baru, namun merupakan modifikasi dari korteks yang mengalami peluruhan (lisis).

Pembentukan dan perkembangan aerenkima, sebagaimana pneumatophore menggunakan energi dari cadangan karbohidrat, pati, dan sukrosa melalui respirasi anaerob (Visser \& Pierik, 2007). Etilen dipercaya berperan dalam pembentukan aerenkima, kemungkinan dengan cara memacu kematian sel yang terprogram di lokasi yang spesifik (korteks) 
(Voesenek \& Bailey-Serres, 2015). Perubahan struktur korteks akar diduga juga disebabkan oleh meningkatnya aktivitas enzim pelunak dinding sel dan dengan deposit suberin pada epidermis.

\section{SIMPULAN}

Terjadi interaksi nyata antara tingkat genangan dan salinitas terhadap pertumbuhan dan anatomi akar yang diamati, kecuali pada luas epidermis akar primer dan sekunder, korteks akar sekunder, dan stele akar tersier. Salinitas tinggi dan genangan menyebabkan penurunan pertumbuhan kelapa sawit. Penurunan yang disebabkan oleh salinitas tinggi lebih besar dibandingkan yang disebabkan oleh genangan. Genangan non salin maupun salin menginduksi adaptasi morfologis berupa terbentuknya pneumatophore dan adaptasi anatomis berupa terbentuknya saluran aerenkima. Salinitas tinggi yang diikuti oleh genangan dapat mengkompensasi pengaruh negatif dari ion garam $\left(\mathrm{Na}^{+}\right.$dan $\left.\mathrm{Cl}^{-}\right)$melalui adaptasi morfologis, perubahan laju serapan ion, dan impermeabilitas membran akar.

\section{UCAPAN TERIMA KASIH}

Peneliti berterima kasih kepada Kebun Penelitian dan Pendidikan (KP2) Institut Pertanian Stiper Yogyakarta yang telah menyediakan lokasi dan bahan tanam untuk penelitian ini.

\section{DAFTAR PUSTAKA}

Acosta-Motos, J. R., Ortuño, M. F., BernalVicente, A. Diaz-Vivancos, P., SanchezBlanco, M. J. \& Hernandez, J. A. (2017). Plant responses to salt stress: adaptive mechanisms. Agronomy, 7, 18-56. https://doi.org/10.3390/agronomy701 0018

Ashraf, M. A. (2012). Waterlogging stress in plants: A review. African Journal of Agricultural Research, 7(13), 19761981. DOI: 10.5897/AJARX11.084

Batool, N., Shahzad, A \& llyas, A. (2014). Plants and salt stress. International Journal of Agriculture and Crop Sciences, 7(14), 1439-1446. Retrieved from www.ijagcs.com. IJACS/2014/714/1439-1446

Chen, T., X. Cai, X. Wu, I. Karahara, L. Schreiber, \& J. Lin. (2011). Casparian strip development and its potential function in salt tolerance. Plant Signaling and Behavior, 6(10), 14991502. https://doi.org/10.4161/psb.6.10.1705 4

Corley, R. H. V. dan P. B. Tinker. (2015). The Oil Palm. West Sussex: Blackwell Science.

Duarte, H. H. F. \& E. R. de Souza. (2016). Soil water potentials and Capsicum annuum L. under salinity. Revista Brasileira de Ciência do Solo, 40, 1-11. DOI: 10.1590/18069657rbcs20150220

El-Nashar, W. Y. (2013). The combined effect of water-logging and salinity on crops yield. IOSR Journal of Agriculture and Veterinary Science, 6(4), 40-49. DOI: 10.9790/2380-0644049

Fakhrfeshani, M., Shahriari-Ahmadi, F., Niazi, A., Moshtaghi, N., ZareMehrjerdi, M. (2015). The effect of salinity stress on $\mathrm{Na}^{+}, \mathrm{K}^{+}$concentration , $\mathrm{Na}^{+} / \mathrm{K}^{+}$ratio , electrolyte leakage and HKT expression profile in roots of Aeluropus littoralis. Journal of Plant Molecular Breeding, 3(2), 1-10. 
http://dx.doi.org/10.22058/jpmb.2015. 15369

Firmansyah, E., Kurniasih, B., \& Indradewa, D. (2016). Shoot growth and yield of rice (Oryza sativa var. Indica) in the combined submergence and salinity. International Journal of Science and Research, 5(11), 1880-1884. DOI: 10.21275/ART20163171

Firmansyah, E., Kurniasih, B. dan Indradewa, D. (2017). Respon Varietas Padi Tahan Salin Terhadap Beberapa Durasi Genangan dengan Tingkat Salinitas Berbeda. Agroista, 1(1), 65-74. Retrieved from 36.82.106.238:8885/jurnal/index.php/ AGI/article/download/27/26

Foster, K. J. \& Miklavcic, S. J. (2017). A comprehensive biophysical model of ion and water transport in plant roots; Clarifying the roles of endodermal barriers in the salt stress response. Frontiers in Plant Science, 8, 1-18. https://doi.org/10.3389/fpls.2017.013 26

Golldack, D. C. Li, Mohan, H., \& Probst, N. (2014). Tolerance to drought and salt stress in plants: Unraveling the signaling networks. Frontiers in Plant Science, 5(15), 1-10. https://dx.doi.org/10.3389\%2Ffpls.201 4.00151

Lauchli, A \& Grattan, S. R. (2007). Plant growth and development under salinity stress. in Jenks, M.A., Hasegawa, P.M., \& Jain, S. M. (Eds.) Advances in molecular breeding toward drought. Switzerland: Springer. pp 1-32.

Gupta, B. \& Huang, B. (2014). Mechanism of salinity tolerance in plants: Physiological, biochemical, and molecular characterization. International Journal of Genomics, 2014, 1-18. http://dx.doi.org/10.1155/2014/70159 6
Hanin, M., Ebel, C., Ngom, M., Laplaze, L., \& Masmoudi, K. (2016). New Insights on plant salt tolerance mechanisms and their their potential use for breeding. Frontiers in Plant Science, 7, 1787. https://dx.doi.org/10.3389\%2Ffpls.201 6.01787

Henson, I. E., Harun, M. H., \& Chang, K. C. (2008). Some Observations on the effects of high water tables and flooding on oil palm and a preliminary model of oil palm water balance and use in the presence of a high water table. Oil Palm Bulletin, 56, 14-22. Retrieved from palmoilis.mpob.gov.my/publications/O PB/opb56-henson.pdf

Jackson, M. B. \& Colmer, T. D. (2005). Response and adaptation by plants to flooding stress. Annals of Botany, 96(4), 501-505. https://dx.doi.org/10.1093\%2Faob\%2F mci205

Jaleel, C. A., Manivannan, P., Wahid, A., Farooq, M., Al-Juburi, H. J., Somasundaram, R. \& Panneerselvam, R. (2009). Drought stress in plants: A review on morphological characteristics and pigments composition. International Journal of Agriculture \& Biology, 11(1), 100-105. Retrieved from http://www.fspublishers.org/published _papers/84178_..pdf

Jamil, M., Ashraf, M., Rehman, S., Ahmad, M. \& Rha, E. S. (2012). Salinity induced changes in cell membrane stability, protein and RNA contents. African Journal of Biotechnology, 11(24), 64766483.

http://dx.doi.org/10.5897/AJB11.2590

Jenks, M. A. \& Hasegawa, P. M. (2014). Plant abiotic stress. Chichester: John Wiley \& Sons. DOI:10.1002/9781118764374

Jouyban, Z. (2012). The Effects of salt stress on plant growth. Technical Journal of 
Engineering and Applied Sciences, 2(1), 7-10. Retrieved from www.tjeas.com

Kim, H., H. Jeong, J. Jeon, dan S. Bae. (2016). Effects of irrigation with saline water on crop growth and yield in greenhouse cultivation. Water, 8(4), 127. https://doi.org/10.3390/w8040127

Koon, L. W. \& Kun, O. B. (2006). The Unseen Flood: Waterlogging in Large Oil Palm Plantations. Jurutera, Januari 2006, 28-31. Retrieved from dspace.unimap.edu.my/.../1/028_030_ 031_unseen\%20flood

Li, H., J. Yi, J. Zhang, Y. Zhao, B. Si, dan R. L. Hill, L. Cui, \& X. Liu. (2015). Modeling of soil water and salt dynamics and its effects on root water uptake in heihe arid wetland, Gansu, China. Water, 7(5), 2382-2401. https://doi.org/10.3390/w7052382

Machado, R. M. A. \& Serralheiro, R. P. (2017). Soil salinity: Effect on vegetable crop growth, management practices to prevent and mitigate soil salinization. Horticulturae, 3(2), 30. https://doi.org/10.3390/horticulturae3 020030

Magdy, M \& Mansour, F. (2016). Protective effect of 24-epibrassinolide against salt-induced destabilization of plasma membrane. International Journal of Advanced Research, 4(5), 488-492. http://dx.doi.org/10.21474/IJAR01/394

Morales, S. G., Trejo-Téllez, L. I., Merino, F. C. G, Caldana, C., Espinosa-Victoria, D. \& Cabrera, B. E. H. (2012). Growth, photosynthetic activity, and potassium and sodium concentration in rice plants under salt stress. Acta Scientiarum, 34(3), 317-324. doi: 10.4025/actasciagron.v34i3.13687

Munns, R. (2002). Comparative physiology of salt and water stress. Plant, Cell and Environment, 25(2), 239-250. https://doi.org/10.1046/j.0016- 8025.2001.00808.x

Negrao, S., Schmockel, S. M., \& Tester, M. (2017). Evaluating physiological responses of plants to salinity stress. Annals of Botany, 119(1), 1-11. https://dx.doi.org/10.1093\%2Faob\%2F mcw191

Nishiuchi, S., Yamauchi, T., Takahashi, H., Kotula, L., \& Nakazono, M. (2012). Mechanisms for coping with submergence and waterlogging in rice. Rice, 5(1), 2 . https://doi.org/10.1186/1939-8433-5-2

Parent, C., Capelli, N., Berger, A., Crèvecoeur, M., \& Dat, J. F. (2008). An overview of plant responses to soil waterlogging. Plant Stress, 2(1), 20-27.

Ponnamperuma, F. N. (1972). The chemistry of submerged soils. Advances in Agronomy, 24, 29-96. Retrieved from www.garfield.library.upenn.edu/.../A1 983QQ90500001.pdf

Rivera-Mendes, Y. D., Cuenca, J. C. \& H. M. Romero. (2016). Physiological responses of oil palm (Elaeis guineensis Jacq.) seedlings under different water soil conditions. Agronomía Colombiana, 34(2), 163-171. Retrieved from

http://www.redalyc.org/articulo.oa?id $=180348900005$

Salazar, C., Hernández, C. \& Pino, M.T. (2015). Plant water stress: Associations between ethylene and abscisic acid response. Chilean Journal of Agricultural Research, 75(1), 71-79. http://dx.doi.org/10.4067/S0718$58392015000300008 \mathrm{~h}$

Shannon, M. C. (1997). Adaptation of plants to salinity. Advances in Agronomy, 60, 75-210. Retrieved from http://agris.fao.org/agrissearch/search.do?recordID=US974217 2

Shaw, R. E. (2015). Plant waterlogging: causes, responses, adaptations and 
crop models. Thesis. School of Earth and Environmental Sciences University of Adelaide.

Tang, X., Mu, X., Shao, H., Wang, H.\& Brestic, M. (2015). Global plantresponding mechanisms to salt stress:Physiological and molecular levels and implications in biotechnology. Crit. Rev. Biotechnol. 35, 425-437. https://doi.org/10.3109/07388551.201 4.889080

Visser, E. J. W. \& Pierik, R. (2007). Inhibition of root elongation by ethylene in wetland and non-wetland plant species and the impact of longitudinal ventilation. Plant, Cell and Environment, 30(1), 31-38. https://doi.org/10.1111/j.13653040.2006.01601.x

Voesenek, C. J. \& Bailey-Serres, J. (2015). Flood adaptive traits and processes : an overview. New Phytologist, 206(1), 5773. https://doi.org/10.1111/nph.13209

Wegner, L. H. (2010). Oxygen transport in waterlogged plants dalam Mancuso, $\mathrm{S}$. dan Shabala, S. (ed.) Waterlogging Signalling and Tolerance in Plants. Berlin: Springer-Verlag Berlin, 1-294. 